هجلة الفنون والأدب وعلـوم الإنسانـيات والاجتهـاع

Journal of Arts, Literature, Humanities and Social Sciences

www.jalhss.com ISSN online: 2414-3383 ISSN print: 2616-3810

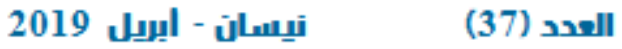

\title{
Bedouin Woman Challenges Patriarchal Oppression in Miral Al Tahawi's The Gazelle Tracks
}

\author{
Zainab Abd Ali Hammood,Lajiman Bin Janoori \\ Pendidikan Sultan Idris University(UPSI),Tg.Malim, Perak, Malaysia \\ E-mail: zainab.alhammood@gmail.com
}

\begin{abstract}
Bedouin women suffer from strict restrictions imposed by traditional customs in Bedouin society, where men are the main focus of the family and society. This privilege granted by society to men makes them responsible for making decisions and controlling the fate of their family members, especially women who are considered ineligible for decisions that affect their lives, or less than men. In this research, the problem of Bedouin women will be highlighted as a victim of strict Bedouin patriarchal values through the study and analysis of Hind's character in Miral Al-Tahawi's novel The Gazelle Tracks. The study adopts the radical Feminism theory, which believes that the basis for the oppression of women is the patriarchal system, will enable the reader to understand the influence of patriarchy on the female characters as the "other" or less valuable than men in the patriarchal system. The study leads to the conclusion that women may resort to the cruelest methods of "death" as a challenge to parental norms that violate their rights.
\end{abstract}




\section{INTRODUCTION}

With the Feminist movements in the late 1960s and early 1970s that emerged in America and Europe, the feminist system saw patriarchy as the social control of those who represent the weakest link in society. Patriarchy is also defined as racist, colonial or class based on gender relations. The concept of patriarchy is highlighted in kinship relations in which men dominate women and younger members, as was common in patriarchal ancient civilizations (Millet, 1977).

Millett (1977), claims that patriarchy is the main reason for the violation of women's rights and their oppression in a society ruled by masculine authority. According to Millett, this is due to the loss of justice in the struggle for sex politics. The policy is based on power-based relations, where a group of individuals dominates and controls the other group. Millett believes that the situation is a key element in socialization because the man granted himself a superior position while placing women in the lowest one so that he can maintain and adhere to a high position is not subject to change, which represents the meta-inferiority of women (Millet,1977).

In her book Sexual Politics, Millett (1977) believes that the family is the basic structure of patriarchy because it is the most appropriate place to establish the idea of patriarchy and maintain the hierarchy within it. Within the family, a man, as a husband or father, exercises his authority and his hegemony over women, so that women are of the lowest rank as men. The economic adoption of a woman to her husband is one of the most important reasons for men to rule and control women as long as they are the source of funding for women only. Therefore, Millett sees the concept of patriarchy firmly rooted in society, starting with the family:

Patriarchy's chief institution is the family. It is both a mirror of and a connection with the larger society; a patriarchal unit within a patriarchal whole. Mediating between the individual and the social structure, the family effects control and conformity where political and other authorities are society, the family and its roles are prototypical. Serving as an agent of the larger society, the family not only encourages its own members to adjust and conform, but acts as a unit in the governments of the patriarchal state which rules its citizens through its family heads. Even in patriarchal societies where they are granted legal citizenship, women tend to be ruled through the family alone and have little and no formal relation to the state (Millet,1977: 26).

Kate Millett's sexual politics (1977), is one of the founding works of Radical Feminism, where Millet considers this ideology to be highly pervasive and provides a deeply rooted concept of power According to Millett the sexual relationship within the family gives the father a superior position by controlling and dominating the family members, while the women and children of the family are subject to the fact that they are lower than men. The status of women and children accept their inferior roles that deprive them of taking their natural role and deprives them of doing business as a natural thing in society. Therefore, civilization as a whole accepts the privileges granted by man to himself, through which women were excluded from their natural role in society:

It is one which tends ... to be sturdier than any form of segregation, and more rigorous than class stratification, more uniform, certainly more enduring... Our society, 


\section{العدد (37)}

2019 نيسان - ايرِل

مجلة الفنون والندبوعلوم الإنسانيات والاجتهاع

like all other historical civilizations, is a patriarchy. The fact is evident at once if one recalls that the military, technology, universities, science, political office, and financein short, every avenue of power ... including the coercive force of the police, is entirely in male hands ... What lingers of supernatural authority, The Diety, "His" ministry, together with the ethics and values, the philosophy and art of our culture-its very civilization—as T S. Eliot once observed, is of male manufacture" (Millett, 1977: 52).

Kate Millett claims that all males as overly aggressive and sadistic against female:

Emotional response to violence against women in patriarchy is often curiously ambivalent; references to wife beating, for example, invariably produce laughter, and some embarrassment. Exemplary atrocity, such as the mass murders committed by Richard Speck, greeted at one level with a certain scandalized, possibly hypocritical indignation, is capable of eliciting a mass response of titillation at another level. ... In view of the sadistic character of such public fantasy as caters to male audiences in pornography or semi pornographic media, one might expect that a certain element of identification is by no means absent from the general response. Probably a similar collective frisson sweeps through racist society when its more 'logical5 members have perpetuated a lynching (Millett, 1977: 45).

For Kate Millett women controlled and socialized by their families. Males' domination is given to reinforce and support by the legal rules governing the family (33-35). Millet asserts that to end patriarchy would require the demolition of the shackles that stand against those things threaten "patriarchal, monogamous marriage". Ending the male supremacy ideology will give women the capacity to be emotional, efficient, and intellectual. The canceling of sex roles and the economic independence of woman will define both patriarchal proprietary family's authority and its financial structure. According to Millet, Patriarchal family strengthens its patriarchal position through the economic support it provides to women and children. Since financial equality is almost absent within it, and females are determined in taking care of their houses and children, the traditional division of roles needs male supremacy

Women's lack of formal relations with the state and society leads them to be controlled and formalized by the laws and rules governing the family that strengthen women's vulnerability and men's authority over them. Therefore, the end of the patriarchal system requires the destruction of the prohibitions that stand in the way of giving women their right as patriarchal marriage. These prohibitions include what is against homosexuality, premarital sex, illegality and adolescence. The change of ideology that gives men more superiority than women allows women to take their natural role in society and be more abstract. This will inevitably affect patriarchal property, where the abolition of sexual roles will lead to the physical independence of women and the undermining of parental authority. Millett aurges that patriarchy depends mainly on the economic dependence of women and children on men, so the roles of women are linked to the attention of children, while the superiority of men requires higher roles in society

Millett (1970), stresses that patriarchy is the main reason for the oppression of other women and their consideration in society. Under the patriarchal system, the dominant members of the society are raped, assaulted and terrorized as a means of maintaining their dominance in 
society. Feminist radicalism defines the patriarchal system as a man's control over spheres of work and other professional fields, where women are excluded from workplaces and decisionmaking positions as the lowest in society. Therefore, men dominate women by occupying important positions in all fields. Millett conceives this in her book Sexual Politics:

Our society... is patriarchal. The fact is evident at once if one recalls that military, industry, technology, universities, science, political offices, finances - in short, every avenue of power within the society, including the coercive force of the police, is entirely in male hands (Millett, 1970: 25).

The radical movement focuses on criticizing the political and social organizations associated with paternity. Feminist Radicalism sees patriarchy as the distribution of rights and privileges on the basis of gender, so the task of radicalism is to eliminate the dominance of men in society. Radical Feminism encourages women's independence and takes their natural role in society away from gender discrimination. Radical feminists deals with gender-based persecution as a form of repression of women and focuses on women's issues that transcend race and class. (Jaggar, 1983).

Firestone, In her book "Redstockings of the Women's Liberation Movement" states that women are controlled by capitalists:

Our oppression is total, touching every facet of our lives. The concept of the radical feminist movement is based on oppression and domination, which is imposed on women by the patriarchal system, which is the main cause of women's inequality and male domination in society (Firestone, 1974:14).

Kate Millett (1977), claims that sex policy since history is based on the principle of male domination and subordination of women, and emphasizes that " reside in physical strength but in the acceptance of a value system which is not biological"(P.27). Mellitt claims:

Because of our social circumstances, male and female are really two cultures and their life experiences are utterly different- and this is crucial. Implicit in all the gender identity development which takes place through childhood is the sum total of the parents" the peers" and the culture's notions of what is appropriate to each gender by way of temperament, character, interest, status, worth, gesture, and expression. Every moment of the child's life is a clue to how he or she must think and behave to attain or satisfy the demands, which gender places upon one....to take a simple example: expectations the culture cherishes about this gender identity encourage the young male to develop aggressive impulses, and the female to thwart her own or turn them inward" (Millet, 1977, p. 31).

Therefore, gender is a pattern that has been preserved for the benefit of the dominant group, roles are accordingly distributed as the intelligence, and effectiveness and strength of males while the share of woman's ignorance, obedience, and virtue. Therefore, the priority for males is to build stereotypes that perpetuate women's subordination. In the view of the Radical feminist, women must show their abilities to confront male domination and express their voice and vision and describe the experiences of other women. 


\section{Methodology}

The text will be analyzed in this work by translating and deducing the texts objectively. Quotations that embody patriarchal oppression against Bedouin women and the suffering of Bedouin women and their reaction will be the basic material and data for this research work. Radical feminists' ideas will be adopted in the status of woman in the patriarchal customs practiced by the patriarchal society against women in Miral al-Tahawi's The Gazelle Tracks.

\section{Literature Review}

The Arab society is governed by the patriarchal system, where the man is seen as the centerpiece of the family, which controls and dominates the entire family. All members of the family are subject to his authority and follow his orders and he has absolute authority to act and take decisions about them. The patriarchal structure of the Arab society is not confined to the family, but exists in all the pillars and strata of society. Young men and women in society are identified in various aspects of life according to the rules and customs of society. In the Arab rural society, tribal leaders retain the power and authority to impose control over those who are less than them and control the material resources (land, wealth and livestock). In this patriarchal system, roles are directed to males to impose their control in order to protect the family and its honor (AlKrenawi, 2000).

Sexual roles have been given since childhood, where girls are raised to be obedient to male and to act with restraint to preserve the honor of the Bedouin family, while males are taught to watch their sisters and revenge for honor. Male is characterized by complete freedom to move out of the house and to mix with others while females are forbidden to do so. In addition, strict Bedouin customs allow elderly women or grandmothers to impose their control over women and to control them and make them subject to male authority. Evaluation of children in the Bedouin family is subject to a gender hierarchy where males are preferred to females and thus have more power and power in the family and society. The brother can control his sisters and family women in the absence of his father (Al-Krenawi and Graham, 1999).

Patriarchal values are maintained through a deep network of norms, constraints and values that the Bedouin society insist to keep to maintain a hierarchy. Men are superior to women through gender roles, while women are held responsible for family honor through their behavior and self-control. This comes from the Bedouins' view of women as seductive and therefore observable to preserve honor. In addition, women's movements are limited by their family members and are subject to varying degrees of discrimination (Al-Krenawi, 1999)..

In marriage, women have no role in the choice and their objections are not heard or rejected. Often, the decision is made by the dominant men. Marriage is an agreement between the families which are often close (Mass and Al-Krenawi, 1994; Abu-Lughod, 1986). At the same time, it is completely forbidden to contact men or women in any way or even to meet or be courted. Women who doubt their contact with one of men are subjected to severe punishment and suffocating restrictions. Romantic relationships are considered a failed basis for marriage and the wife is chosen by the husband's family on the basis of reputation and economic status (Hana, 1984; Moors, 1995). 


\section{العدد (37)}

Moreover, the status of a woman as a wife in the family depends on the number of males she give birth to them because they consider the real force and the axis of the Bedouin family, and women should have no shortfall in having children (Al-Krenawi,1998b). Bedouin women are subjected to significant discrimination in Bedouin society through two main factors in the system of society, "gender and group" where women are exposed through sex to discrimination and great pressure and control of their role in reproduction, which is subject to male will increase the number of male children (Abu-Lughod,1986). Also for girls, they are prohibited from going out and mixing with others and women wear long, decent clothes (Peters,1990).

As for the group, women are marginalized at the level of Bedouin society and are married to satisfy the interests of the group rather than their own, where marriage is based on relations and interests between families and tribes and to increase the size of power and community (AbuOdeh, 1993). Gender and the community are severe restrictions on Bedouin women, where women are prevented from education and work so as not to interfere with foreign men or bring bad reputation to their families. In her study, (Abu-Lughod,1986) recalls that Bedouin women in Egypt show a form of rebellion and underground resistance, such as dance alone, where dancing is considered a defect or chatting with one another in the absence of men. This is a useful strategy for Bedouin women under strict male restrictions where they can exercise their freedom while men are absent.

\section{Data analysis}

Miral al-Tahawi in her novels The Gazelle Tracks (2008), presents us with a vivid picture of the Bedouin community and the suffering of women as a lower class in the society. Al-Tahawi reveals to us the extent of the persecution that Bedouin women face in a society where men are the center of the universe, through the tragedy of the heroine Hind. The novel tells the story of Hind, who is forced to marry her cousin who betrays her and injures her dignity, ending up marginalized and isolated by society to surrender to death as a punishment for refusing to submit to and stay with her husband.

Through Al-Tahawi's novel, the reader witnesses how the Bedouin society maintains strict norms and values as part of the maintenance of sexual politics. Muhra, who is looking for the truth about her mother, explains to us that her mother was a victim of harsh Bedouin customs, where she was married to Muhra's father against her will. As is common in Bedouin society, women are given wives to their cousins without taking their opinion or referring to them. Al Tahawi also reminds us of some of the stories that justify the oppression of women by virtue of honor as a hidden story that threw his daughter in the river to die drowning to marry a Turkish man. This represents the dominant and oppressed man in the Bedouin society, who has the right to practice freely in all stages of his life. The story of Muhra's father who has had sex with maids in absolute freedom since he was a teenager, while Hind is prevented from practicing hobbies such as dancing, listening to music, or reading novels.

Al-Tahawi reveals to us how Bedouin society gives men the right to education while women are prevented from doing so. The eldest brother of India travels to the United States to study law and marries a Lebanese woman while his sister is prevented from reading a novel where he beat her to the noses of her nose and tore the novel. 


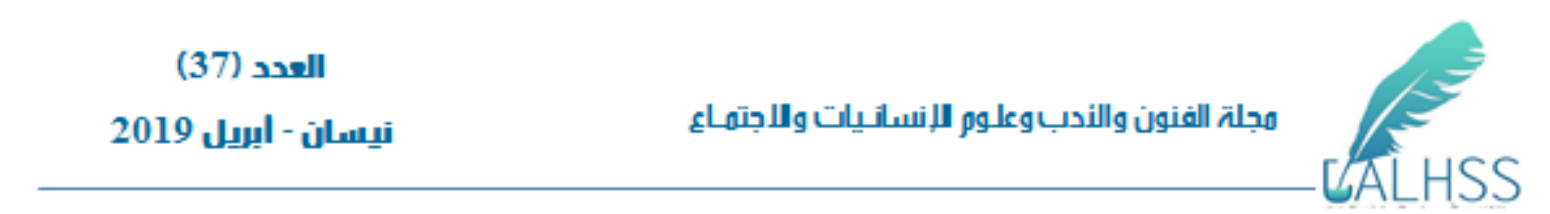

We also discover this through the words of the father who sees that education for girls is a failed experience and that he corrupted Hind's uncles.

Birkam is the only foreigner who has been allowed to enter the Bedouin community as an explorer who digs deep into the Bedouin customs, customs and values. He may have occurred in the heart of Hind, but she is fully aware of the impossibility of this relationship and her fate will be the fate of every Bedouin girl goes beyond the limits of Bedouin values. Al-Tahawi follows Hind's story and how she is oppressed by her brother, who deprived her of dancing, singing or reading, and is forced to marry her cousin who neglects her and injures her in betrayal with the other women, ending up in madness and death.

On the contrary, her cousin practices his absolute freedom in the Bedouin society, where he has sex with the maids. This does not affect his reputation because he is male and according to the Bedouin customs, he does not bring disgrace to his family or his clan: "Boys at that age turn into stallions. They're like male camels on heat"(Al Tahawi, 2008: 2).

Thus, the extent of discrimination between the two sexes is evident in patriarchal society, where males enjoy great freedom, encouraging even the mistakes they make, and even trying to find excuses and justifications for their actions, while women are barred from any work outside the customs even from thinking aloud. According to Kate Millet, men are given the right to exercise what they want as a supreme authority, while women are banned and their roles remain dependent on attention because they are followers: "What he needs is an hour with Fatima $\mathrm{Al}$ Gurummiyya"(Al Tahawi, 2008: 2).

In this text, everyone is looking for excuses and justifications for the work of men, and even suggests that spend a night with Fatima Qaroumiyah. Miral Al Tahawi reveals the duality of the masculine society that abuses Hind, because she refuses to stay with a traitorous husband, while accepts her husband's actions and betrayal as part of the Bedouin man's personality in a patriarchal society. Perhaps this is why Hind has led since childhood to carry a small pamphlet to codify its secrets, because she knows that society does not want to hear her thoughts or or is forbidden to disclose what she things of: "Everywhere she went, Hind carried an exercise book in which she recorded the secrets that no one else knew"(Al Tahawi, 2008: 2).

Hind carries the exercise book means that she lives in a patriarchal society that stifles her thoughts and aspirations in her mind. Hind knows through everyday life that the society is so cruel that it does not have mercy on her. Hind finds safety and refuge in writing her thoughts in the privacy of the booklet away from the suffocating restrictions that surround her. Hind as a girl living in a male society often practices her hobbies secretly, but in the end she is suppressed by her brother Nafidh:

Those who knew Hind said that she used to play records to learn how to dance the jive and do the twist. She would sit on her own trying to sing like Fathiyya Ahmed, and she would recite passages from the Lady of the Camellias in a trembling voice under the trees in the garden ( $\mathrm{Al}$ Tahawi, 2008: 48).

The brother's behavior with his sister gives us a clear picture of how a woman is fought and oppressed in her simplest rights, such as reading, while a man (her brother Nafidh) enjoys all his rights. 
He is allowed to travel, study and marry a foreigner. Depriving Hind of reading or practicing her hobby comes as a result of male fears that she will realize her rights and rebel against those patriarchal values:

Then her brother, who now lives in New Jersy, noticed what she was doing. He tore up the novel she had borrowed from Miss Angela, the headmaster's daughter, and punched Hind in the face(Al Tahawi, 2008: 48).

The tearing of the novel refers to the extent of the fear that dominates the males. Males are afraid that women will become aware of their rights and oppress them and rebel against those patriarchal customs that restrict them. The rebellion of women in the male perspective is an insult to them and departure from patriarchal authority. Therefore, male practices violence as a means of suppressing women and preventing them from reading and learning, as happens with Nafidh hits his sister Hind, when he discovers that she is reading.

Through the narration of the child Muhra, Al Tahawi reveals the brutality and harshness of patriarchal patriarchal customs imposed on women. Muhra looks at a picture hanging on the wall which intrigues her to know who that little girl?The answer is always " poor thing" (Al Tahawi, 2008, p.3). This phrase refers to the angry of the family as a result of the rebellion of Hind, and the extent of the marginalization that Hind had encountered.

Muhra tells us about the tragedy of her mother Hind, who refuses to marry her cousin, but is forced to marry him. Hind's rejection or her opinion of that marriage has little value in patriarchal society. Women are the absolute property of a man who has the right to dispose of her and give her a wife to whom he wishes. Hind is incarcerated after refusing to live with her husband in an isolated place and leaving them vulnerable to disease, hunger and death, so they did not answer and did not grieve because, according to the patriarchal concept, she tarnishes the reputation of the clan and defied Bedouin customs: "They didn't wail or weep or even put on their mourning clothes"( Al Tahawi, 2008: 3).

The text above shows the sense of shame of Hind's behavior and her rebellion against patriarchal values. The society is forced to isolate her, leave her alone and fight her to death as a punishment. She becomes an example of women who are trying to rebel. The prevention of grief and crying is to reveal the extent of the ostracism that has been exposed to her and to show that those who rebel against the male sentences are easy prey to the punishment and the most severe penalties applied by the society without mercy:

They had pronounced her dead long before, from the day they had placed her in that house, shut up the windows and doors and walked away, headless of her screams ( $\mathrm{Al}$ Tahawi, 2008: 3).

The family avoids others to talk about Hind and all what is said about her is poor thing when looking at her picture, because she does not deserve to be talked about or mention her for violating the Bedouin customs and rebelled against the provisions of male power and caused a disgrace to her family. Bedouin society is keen to do talk about it forgotten because it may inspire other women to rebel: "poor thing, they said, and then never mentioned her name again"(Al Tahawi, 2008: 3). 


\section{العدد (37)}

This cruelty directed against Hind comes from the background of customs, values and maculine laws that have been dedicated to subjugate the female and make her an easy prey to satisfy the man. Bedouin families often focus on teaching their daughters that the satisfaction of men is very important and that they must be obedient, submissive and subject to the most severe penalties imposed by patriarchal authority. This is clear from the advice of Amma MIzna to muhra:"You are not an easy prey to catch... in order to remind her that she was a daughter of the Arabs"( Al Tahawi, 2008: 7).

The attempt to control the girls makes them passive and ignorant of their rights, is illustrated by the father's words, which mention that the boarding school has corrupted his sisters and that he opposes the idea of girls education. His word for Mahra is instructing her that education does not benefit her and causes her corruption: "Her father didn't agree with boarding schools and he told Muhra that they had ruined the mind of her mother and aunts"( Al Tahawi, 2008: 8).

The father in the above statement may reflect his fears of Muhra's rebellion, as her mother did, but he does not refer to her mother, because no one of the new generations should know of her rebellion. Reminding Muhra that the study had corrupted her aunt shows the father fears that the education comes with the ideas of changing the Arab girls to become defiant of the traditions of society. The fears of the father, which makes him think a lot about the matter of his daughter, make him tell her stories through which he can control her and make her subordinate as the masculine society wants. So, when Muhra attends school, she is accompanied by a maid and forbidden to mix with others in school or class. Her father makes orders that no one sits or speak to her for fear that she would be influenced by someone's ideas that contradict the values and customs she learns at home. It is an attempt to discipline the child so that she does not exceed the limit of her behaviors according to what she taught at home: "on the shoulder of a black slave girl"( Al Tahawi, 2008: 8).

Moreover, the father intensifies his advice to his daughter and reminds her that the Bedouin woman must be submissive and obedient to the authority of men and never leave them. He is proud to mention stories that focus on masculine autorithy before his guests and his daughter Muhra, stressing that women must follow Bedouin teachings. He points out that he married his cousin because she would be his wife even if he did not ask for marriage:

A girl will marry her cousin even If it is the last thing she wants. An Arab girl's like an obedient she-camel: the place you tether her, that's where she knnls, the place you lead her, that's where she goes (Al Tahawi, 2008: 42).

The words of the father refer to the reality that the Bedouin woman is completely subject to the authority of the male and that the man is issuing orders to her and controlled by how he wishes, and therefore all the rights of women as their right to choose their partner or to show their opinion decided by men: "Even if she's in the howdah on her way to wed a stranger, she'll jump down and marry

Muhra sits in the lap of her father listening to his stories, in which he stresses the oppression of women and compels them to obey men's orders. Otherwise, any opposition or violation of patriarchal values, even if they have no guilt, will lead to their death. It reminds them that the woman who intends to marry a peasant will be be thrown to the crocodile. (The peasant here means any non-Bedouin man). 


\section{العدد (37)}

2019 نيسان - ايرِل

مجلة الفنون والندبوعلوم الإنسانيات والاجتهاع

Muhra notes that the listeners of her father's talk shake their heads as an endorsement of his words: "we'd sooner throw her to the crocodiles than have her marry a peasant"(Al Tahawi, 2008, p.13).

In the above paragraph, it is clear to us the extent of the suffering of Bedouin women who seem to fall victim to the strict patriarchal values directed at them. Repression and oppression of Bedouin women by patriarchal society is a constant suffering that women often face with complete silence and sometimes rebellion that may lead to punishment or even death for violating the patriarchal values they wish to be silent and surrendering.

Al-Tahawi, therefore, points to an important point in her society: reminding women that they must follow the patriarchal nomadic tradition, or else they will be like grandmothers who fight against these customs. From here, men are keen to recall stories that happened to women around them as the story of the daughter of Grandfather Mahjoub, whose father preferred to throw her in the river to die drowning on the marriage of King Abbas, the king of Egypt, who asked for marriage. Bedouin women do not marry non-Bedouin men because this does not extend to strict Bedouin traditions. So the fate of the daughter of Mahjoub death, drowned in the river so that her father is not forced to marry the king of Egypt:

They had thrown her into the river for the crocodile to eat so that she would forever remain a through red and not mounted by a peasant, even if he were Abbas I, son of the Sultan of Egypt( Al Tahawi, 2008: 28).

Moreover, these customs are purely masculine and are applied to Bedouin women to limit their freedom and control their lives, with women expected only to subordinate and obey male authority. The Bedouin man surrounds himself with a great aura of freedom and acts according to what he wants, where there are no restrictions or customs that prevent him from doing so. For example, Hind's brother is completing his studies in the United States while Hind is prevented from completing her studies. Nafidh is also married to a non-Bedouin woman in the United States, while Hind is forced to marry her cousin, who betrays her. According to the patriarchal concept of Bedouin society, Nafidh as a male, his traveling abroad and marrying a foreigner woman does not spoil the reputation of the Bedouin family. Thus, it is clear that Bedouin society distributes gender roles as follows: deprivation, excessive restrictions on women, and excessive freedom of men:

A few months after he sent them a picture of his wedding in California or New Jersy, with all the cards and telegrams of congratulation, and a photoghraph of his Lebanese wife (Al Tahawi, 2008: 21).

Nafidh who travels to the USA and marries to a Lebanese woman there, remembers the tragedy of Hind and shows him Massey and Alma as a result of her marriage to her cousin who constantly cheats on her and neglects her feelings. Navid always feels that he was the cause of Hind's tragedy because he was watching the men in the family who fought her freedom and forced her on the façade. Perhaps this feeling of salvation comes from the impact of his new life in a more liberal society and his marriage to a liberal woman: "He could never forget that he was the one who had caused it all to happen"(Al Tahawi, 2008: 22). 


\section{العدد (37)}

2019 نيسان - ايرِل

مجلة الفنون والندبوعلوم الإنسانيات والاجتهاع

Al-Tahawi continues to expose her to the oppressive norms that Bedouin women meet at the hands of the masculine authority, where we are transferred to the customs and practices that take place on the night of the wedding. girls are tortured physically and psychologically on the wedding night. Through the heroine Hind, we see how the bride is treated on the night of her wedding. Fatima al-Qaroumiya, the woman who prepares brides for their husbands on the night of marriage, takes Fatima to bed and removes her virginity with her fingers. Hind remains locked in these cruel customs and restrictions and tears to violate her dignity and body in such a heinous way. Fatima al-Qaroumiya graduated to find the husband waiting for her at the door to tell him that she has ended his wife's virginity. Hind hears the laughter of the husband and Fatima Al-Qaroumiya as she surrenders to tears, psychological pain and internal defeat:

Then they left her to Fatima Al-Gurumiyya.... Having completed the ritual,Multing and Fatima Al-Gurummiyya emerged from the room together and left Hind inside to swallow her tears as she listened to the two of them laughing and smelled their tobacco in the distance ( Al Tahawi, 2008: 52).

As a result, a new phase of humiliation, insulation, and deprivation of freedom and restrictions on Hind's new married life begin. Where she begins a new life full of insults and betrayal and the deliberate neglect by her husband (her cousin), who believes that his betrayal and neglect of her is a part of his Bedouin character, which is not held accountable by the Bedouin community patriarchal, while Hind remains captive to those customs that violate the right and dignity spend her day and night Waiting for the return of her husband, who spends his time with Fatima AlQaroumiya, without caring about the feelings of his small wife: "Hind used to stand there for ages waiting for him to return from Fatima Al Gurumiyya's house"( Al Tahawi, 2008: 53).

Hind's husband's neglect and betrayal, with the approval and welcome of the Bedouin community, makes Hind's life as a hell, suffering and endless tragedy. Hind decides to run away from her husband's house after she had been waiting for her husband to return after spending nights with other women. She views that escape to her parents' house is better than to stay with her husband, even if he is worse than the house of his husband, but she sees no better solution than to escape and to distance herself from the man who humiliated her dignity in such a humiliating manner:"She promised that she would live as a servant in her father's house: Please don't send me back to him,... I'll die if you send me back"( Al Tahawi, 2008:53).

As a Bedouin family following the patriarchal Bedouin traditions, Hind's family stands against her in her decision. Hind faces charges from her family that woman should obey her husband and stay at home, even if he betrays her and she must be patient for his ill-treatment or bad morals. They also remind her that her escape from her husband's house is a disgrace to Bedouin women and thus spoils the reputation of her family: "Everything was up to the woman and she should make more effort with him because all men behave rashly and then come to their senses"(Al Tahawi, 2008:.53).

Miral al-Tahawi tries hard to find the suffering of Bedouin women in a strictly patriarchal society through Hind's experience with her husband, neglecting her family and not appreciating his feelings in her ordeal: 


\section{العدد (37)}

You'll do what your family says, even if it breaks your back. You'll go back to him, you'll go back! You can walk up and down, but you'll go back. He is your father's brother's son and you'll stay in his house till the day you die( Al Tahawi, 2008: 54).

Hind collides with a strong opposition of her family to her behavior and rebukes her and urging her to return to her parents' house because her escape from her husband's house, according to their opinion, will spoil the reputation of the family and evade the Bedouin customs and traditions. Hind realizes that her suffering from the tragedy that she lives makes all stands against her and holds her to blame. No one understands her feelings or what she feels. Everyone supports her husband and considers betrayal and neglect as something natural that does not need to escape or anger. Here, Hind decides to escape this world in its own way, completely neglecting itself and cutting off eating, drinking and caring for itself. Hind turns into another creature that rejects life and refuses to pay attention to herself until she has urinated on her clothes and refuses to be cleaned by anyone. She stands all day outside like crazy. Hind does not talk all day, making the people around her bring her back to her to mind by pouring cold water on her, but all this does not bring Hind back from her absence and her tragic situation.

All attempts to make them regain her consciousness fail. Hind goes every night to the courtyard and stands completely naked there. She begins to lose the feeling around her and cannot hear their calls or words. She escapes her bad reality in such a painful way, which makes the maids take her and her belly to bed from her legs. "They bound Hind by the legs and tied her to the bed"( Al Tahawi, 2008: 38).

Hind still suffers from neglect of herself and her mind and receives strange looks and whispers among her family members of her miserable state, but she does not understand anything of what they whisper. She understands only that they want her to be a subject to her betrayer husband and bad Bedouin customs: "She didn't cry after that. Even so, the servants had to go out and fetch her when she went out at night and stood stark naked in a stupor under"' Al Tahawi, 2008: 5).

Hind knows that all those around her give up and that the only way to stand with her is to be subject to the authority of the patriarchal community and obey her husband in his betrayal and neglect, so she surrenders to her unit and tears and digging the wall with her fingernails as a kind of emptying the pain inside:"Hind would curl up on the bed and peer towards them. She would weep and succumbed to fits of sobbing and wailing, and scratch the walls with her fingernails"( Al Tahawi, 2008: 39).

Hind loses all the means of communication around her. She lives as a passive, inconspicuous, unconscious person. Hind's situation is the result of the pressure, pain, and indignity that Hind, who could not bear the rigor of his life, had to endure. Hind has been marginalized and discriminated from childhood, from depriving her of her hobbies, such as reading, dancing, listening to music and depriving her of completing her studies as a naughty sibling, forcing her to marry her cousin, who continued to humiliate her and injure her.

Hind's absence from the ocean surrounding her and the stifling of her mind makes her not see that her young daughter is talented sitting in the lap of another woman who became a new wife to Hind's husband. Perhaps the new woman who took the role of the mother of Hind's daughter accepts her husband's betrayal and thus guarantees the Bedouin society's view of her as a good Bedouin woman who respects her husband's decisions and bears his whims and betrayal: "They 


\section{العدد (37)}

2019 نيسان - ايرِل

مجلة الفنون والندبوعلوم الإنسانيات والاجتهاع

did not know if she was even aware that she had a child sitting submissively in Sahlas's lap"( Al Tahawi, 2008: 40).

Hind decides to surrender to isolation and tears instead of being a miserable wife who dies every day because her husband betrayed her and the whole society stood against her. After finding that everyone agrees that she is a woman who is mistaken for her behavior and that what her husband is doing is a matter that does not deserve to be left or objected to, Hind realized that her pleas and demands that she leave that husband are no longer heard from anyone and that prayer and prayer do not come with any result to solve her problem. Hind surrenders to herself, aware that this is the only way she can respond to her mind and leave everyone behind her. Hind understands that her only survival among the walls is better than living with a man who is neither valued nor respected by humans who do not appreciate her right to practice what she sees fit for her life and to make the right decision. She also preferred unity so much that the dogs' barking sounds and the ghost never returned never frightened her: "This darkness into which she peered didn't frighten her any more"( Al Tahawi, 2008:41).

Hind's behavior demonstrates her ability and determination to overcome the injustice that she is subjected to and to stand firmly against the Bedouin customs that violated her life and privacy. Despite the harshness of the place where she was jailed, she never regrets or rebuff her decision, but goes on to build the sand castles and smash her like her small dreams:

Hind increasingly succumbed to bouts of abject despair, and that brought on her crying fits again. Then she would stare grave and wide-eyed at unknown things that moved about in the darkness, certain that the door of hope was closed like the taciturn walls around her, and that even if she were to get out, an impregnable barriers of isolation would be set up around her(Al Tahawi, 2008: 40).

In addition, Hind has given up living with those who persecuted her. She does not count the nights or days she goes through in her clay prison because she realizes that the days and nights with them are equal in life with them and being alone is much better than staying with her husband.

For her, succumbing to the isolation and disease that seemed to destroy her body and pimples that ate her skin and surrender to death is much better than a life full of humiliation, insulation and unhappiness with a traitorous husband and a contradictory society: "She didn't try to count the days or to record their passing with marks"(A1 Tahawi, 2008,p.41).

For Hind, waiting for death now is the only means available to her to get rid of all the restrictions and customs that restrict her and the tragedies she has experienced as a result of those restrictions. It prefers loneliness, isolation, pain, sickness, and death than to return to a marginalized and subject to an unjust power that compels it to respect and obey a traitorous husband.

\section{Conclusion}

Al-Tahawi reveals to the reader the severity of patriarchal norms and rulings against women who face arbitrary values imposed on them. In The Gazelle Tracks, Hind stands alone in confronting the whole society, including her family, all of whom practice and oppress male norms. They are put in prison and closed doors for fear of screaming or hearing her voice and 
suffocate the challenge inside. Hind's persecution in this harsh form is a dedication to the strict patriarchal norms of Bedouin women. Al Tahawy embodies the role of oppressed women through Hind's character to reveal the extent of the suffering of Bedouin women in the context of masculine norms that suffocate them and restrict their freedom and their voice. Hind struggles in prison and only put her and her breast and sick and faces death, but she did not receive their wishes and did not back down on her decision.

As Muhra tells us that her mother Hind is different since her childhood, she loves life and has hobbies that express her self-reliance and aspiration, such as reading, listening to music and dancing, and practicing her hobbies secretly because she knows that the society around her is forbidden to be free and to have a view. They fear that they will rebel against the Bedouin customs that make them a tool in the service of men.

In spite of all that, Hind has been subjected to abuse since childhood, she is deprived of reading and beated and prevented her from listening to music or dancing and completing her education, but she is stuck in the strings of freedom until the last moment in her life. Her refusal to marry her cousin is evidence of her clinging to her right to view and refuse to live with a traitorous husband, a sign that she refuses to be subject to an unjust male authority at the expense of her dignity.

Therefore, Hind prefers the slower death than to live as the humiliated wife in a society considers her as a man's companion. Her parents and her husband deal to put her in a muddy, wet prison to retreat from her stubbornness and go back to her husband, but everyone is surprised that Hind is determined to continue to break the customs and restrictions that bind them and to challenge the world's fingerprint and disobedience and accept to live alone surrendering to death as a kind of inquiry that surrenders to the will of patriarchal society. Hind sees that death means the eternal freedom that will save her from the tyranny of her husband and the Bedouin community and save her of the mess of cruel customs.

Hind's surrender to death is a message to her daughter Muhra, who now receives Bedouin teachings, that she is the most courageous woman in her society, who justified injustice and stand up to anyone who wants to delude her that the violation of her freedom and rights and her acceptance of her husband's betrayal is acceptable in Bedouin society. She chooses death to face patriarchal norms that are hard to break.

\section{References}

1. Abu-lughod, 1.(1986). veiled sentiments: honor and poetry in a bedouin society. cairo: the american university in cairo press.

2. Abu-Odeh, L. (1993). Post-colonial feminism and the veil: Thinking the difference. Feminist Review, no. 43 (1993): 26-37.

3. Al-krenawi, A. (1998a). "reconciling western treatment and traditional healing: a social worker walks with the wind." reflections: narratives of professional helping 4(3):6-21.

4. Al-krenawi, A. (1998b). Family therapy with a multiparental/ multispousal family. family process $37(1): 65-81$. 
العدد (37)

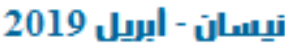

5. Al-krenawi, A. (1999). Social workers practicing in their non-western home communities: overcoming conflict between professional and cultural values. families in society $80(5): 488-495$.

6. Al-krenawi, A., \& graham, j. r. (1999). Social work intervention with bedouin-arab children in the context of blood vengeance. child welfare 78(2):283-296.

7. Al-krenawi, A., \& lightman, E. S. (2000). Learning achievement, social adjustment, and family conflict among bedouin-arab children from polygamous and monogamous families. Social psychology 140 (3): 345-355.

8. Firestone, S. (1974). The Dialectic of Sex : The case for feminist revolution. New York: Morrow, p.4.

9. Hana, N.S. (1984). The desert societies in the arab world. cairo: daar al-marif (in arabic).

10. Mass, M., \& al-krenawi, A. (1994). When a man encounters a woman, satan is also present: clinical relationships in bedouin society. american journal of orthopsychiatry 64(3):357-367.

11. Millett, K. (1977). Sexual Politics. Garden City, N.Y.: Doubleday. Mandell, N.1995. "FemintIssues: Race, Class, and Sexuality" Prentice Hall Canada,Inc.Ontario, p.4-35.

12. Moors, A. (1995). Women, Property, and Islam Palestinian Experiences, 1920-1990. cambridge, uk: cambridge university press.

13. Peters, E. (1990). The Status of Women in The Bedouin of Cryonic. Emanuel Marx and Judy Jideon (New York: Cambridge University Press, 1990), 36. 